Teralita Fadilah Nur Pramuji ${ }^{1}$, Moses Glorino Rumambo Pandin ${ }^{2}$

Faculty of Humanities, Airlangga University

Jalan Dharmawangsa Dalam, Kampus B Universitas Airlangga, Surabaya, Indonesia, 60286

teralita.fadilah.nur-2020@fib.unair.ac.id; moses.glorino@fib.unair.ac.id

\title{
BOOK REVIEW: \\ "FILSAFAT ILMU: SEJARAH, KONSEP, DAN STRATEGI PENGEMBANGAN IPTEKS" (PHILOSOPHY OF SCIENCE: HISTORY, CONCEPT, AND STRATEGY OF SCIENCE DEVELOPMENT)
}

Book Title: Filsafat Ilmu: Sejarah, Konsep, dan Strategi Pengembangan IPTEKS (Philosophy of Science: History, Concept, and Strategy of Science Development); Author: Ade Hidayat; Publisher: CV. ALPHABETA; Print I: 2020; Number of Pages: 288 Pages; ISBN: 978-602-289-575-6

"Filsafat Ilmu: Sejarah, Konsep, dan Strategi Pengembangan IPTEKS" (Philosophy of Science: History, Concept, and Strategy of Science Development) by Ade Hidayat was published in 2020. According to the author, the philosophy of science is one of the courses presented to students as the main source of reference to explore the foundation of science. With the writing of it, the author aims to help students train the way of thinking critically, more deeply, and systematically, to view the problem according to its proportions with the right perspective.

The book explores the whole philosophy of science. It regularly discusses in general philosophy, namely about the understanding and benefits of philosophy, classification of philosophy, the realm of philosophical studies, branches of philosophy; philosophy of science, its development; logic, methods, theories, as well as its history are complete with historical figures, ontology, epistemology, axiology, as well as the development of science and technology.

This book is written in full with a fairly critical language intended to attract general readers, especially for students, to support lecture activities and deepen the material knowledge of the philosophy of science in the philosophy of science courses. The book's content is very informative to make the reader feel satisfied and want to continue to deepen knowledge again.

A book that discusses the philosophy of science as a whole is a book that is recommended for review. This kind of book is very suitable to read for beginners who do not understand the philosophy of science, contains complete content, and is very informative for readers, is common for anyone can read, and obtained from reliable sources. In addition to fulfilling the task of philosophy, this review is expected to attract reading interest and can add insight.

\section{Book Review}

According to the author, the philosophy of science is one of the courses presented to students as the main source of reference to explore the foundation of science. Therefore, the purpose of the book Philosophy of Science written by Dr. Ade Hidayat, M.Pd. is to help students train a critical, deeper, and systematic way of thinking to be able to view the problem according to its proportions with the right perspective.

In its universal writing, it can be intended for students who want to deepen their knowledge of philosophy in philosophy of science and be read by general readers because this literature is general and contains complete content and informative for readers.

Book of philosophy of science can meet the needs of readers who want to explore the philosophy of science more deeply because this book contains a very complete discussion, the readers can know the history of philosophy of science ranging from understanding to develop.

This philosophy book general discusses philosophy, namely about the understanding and benefits of philosophy, classification of philosophy, the realm of philosophical studies, branches of philosophy; philosophy of science, its development; logic, methods, theories, as well as its history are complete with historical figures, ontology, epistemology, axiology, as well as the development of science and technology.

The first part explained the understanding according to some experts, namely according to AlFarabi, according to Aristoteles, according to Immanuel Kant, according to Cicero, according to Plato, according to Johann Gotllieb Fichte, according to Paul Nartorp, according to Notonegoro, according to 
Bertrand Russel, according to Sidi Gazalba, according to Driyarkara, according to Harold H. Titus, according to Muhammad Yamin, Hasbullah Bakry, and according to Ismaun. In general, it can be concluded that philosophy is a philosophy that reviews the nature of science and the basis of science, including social sciences and natural sciences. Related to ontology as well as epistemology. (Pages 1012)

Furthermore, it is explained about the classification of philosophy. Philosophy is classified according to existing cultural customs as well as judging by its geographical location. The classification of philosophy is divided into four, namely Eastern Philosophy (India, China, and Nusantara), Western Philosophy, and Islamic Philosophy. (Pages 13-22)

Western philosophy is generally studied academically at universities in Europe and regions that Europe once colonized. This philosophy originated from ancient Greek philosophy. In western philosophy, it is divided into three parts, namely: Ontology, Epistemology, and Axiology. As for the three crucial characters - Immanuel Kant, Rene Descartes, and Wittgenstein,

Ontology is a field of philosophy that examines existence, epistemology is a field of philosophy that examines knowledge, and axiology is a field that examines value.

Eastern philosophy is a philosophical tradition that grows in Asia, China, the Archipelago, mainly in India, and other regions. A distinctive feature of eastern philosophy is interrelated with religion.

Historically, Islamic philosophy can be said to be the philosopher of this tradition and heir to the Western (Ancient Greek) philosophical tradition. However, there are two opinions on the contribution of philosophy and science of Islamic civilization that continues to grow widely. The first opinion was that Europeans studied philosophy from the Greek philosopher Aristoteles using books. The second opinion explains that the philosophy learned by Europeans came from Greece obtained from a philosophy book that has been translated into Arabic.

The realm of philosophical studies is divided into three main points of study. 1) on the "world" in which an individual life,2) an understanding of "self" of man, and 3) an understanding of the region of "transcendent". The science that understands the world is Cosmology, a branch of philosophy that examines the origin and process of creating the universe. Science that understands about humans there is various kinds, among others Human Philosophy (Philosophical Anthropology), Philosophy of Value (Axiology), Philosophy of Knowledge (Epistemology), Social Philosophy (Social Philosophy), Philosophy of Ethics (Ethics), etc. While the science to understand the problem of transcendence is called Metaphysics (Metaphysics) and transcendent problems about the Creator or God namely Theological Philosophy. (Pages 31-33)

Experts usually say the main branches of philosophy include Epistemology, Logic, Metaphysics, Aesthetics, Ethics, Theology, as well as Philosophy of Science. Schematics of philosophical studies: Philosophy on reality (General metaphysics or called Ontology, Specific metaphysics: Metaphysical Theology, Cosmology, and Anthropology), Philosophy of knowledge (Epistemology, Logic, Scientific Criticism), Philosophy on action (Ethics and Aesthetics), and History of philosophy. (Pages 33-37)

The task of the philosophy of knowledge is to display the answer of how "knowledge of something as it is". In "The Story of Philosophy", Will Duran liken the philosophy of a mariner's army seizing the sea or beach to the landing site of an infantry force. Infantry troops likened to knowledge listed in it there is science. So, it can be concluded that philosophy helps gain a foothold in scientific activities. (Page 39)

In philosophy science has two objects, namely material and formal. A material object is an object used for scientific research or an object that science studies. While formal objects are methods of the approach used material objects, which are typical to characterize or specialized inappropriate activities. (Pages 41-42)

The history of philosophy is divided into four phases of its development as follows: (1) Philosophy of ancient science, from the presence of philosophy to the renaissance; (2) Philosophy of science from the renaissance to the era of positivism; (3) Philosophy of modern era science, from the era of positivism until the end of the 19th century; (4) The philosophy of contemporary science, is the end of the chapter of the development of philosophy of science from the 20th century to the present. (Pages 57-71)

The philosophy of ancient science, recognized as the mother of science in ancient Greece. The Period of Greek philosophy belonged to a very important period because at that time, there was a transformation of the mindset namely, "mitosentris" (the mindset of people who still believe in myths). 
In the Ancient Greek era, philosophy with science was one unity. Philosophy and science are included in the knowledge that is reasonable or rational. (Pages 58-61)

At the time of the renaissance, Renaissance philosophy of science came to a new thought pioneered by Galileo Galilei, Isaac Newton, and Copernicus. Furthermore, in the 17th century, there was progress in science marked by the emergence of Roger Bacon. The next development appeared John Locke, Immanuel Kant, David Hume, and John Locke, the three figures gave considerable development. After that, as it entered the19th century appeared Johann Gottlieb Fichte who presented epistemology. (Pages 61-66)

Philosophy of science in the era of positivism, positivism is a philosophy that evaluates science and scientific methods. Entering the 20th-century developments entered a new era and the formation of a group named the Wina Circle. Wina's circle looks at two issues- theoretical reasoning and knowledge analysis. (Pages 66-68)

The presence of new philosophers characterizes philosophy of contemporary science, the development of this era. (Pages 68-69)

Science evolved over decades and created its epochs, ranging from Ancient Greece, medieval or renaissance, modern centuries, and new centuries of Ancient Greece. (Page 237)

The structure or organization of the content in the book is still not coherently arranged, there are many repetitions of subtitles written to confuse the readers. It would be better if the content and subtitles were written in a more orderly and organized style without repetition.

In addition, this book is equipped with information based on the facts and already contains ideas in it. The facts are obtained from reliable reference material.

Inside this philosophy, book contains quite complete discussions on the philosophy of science ranging from history to its development. It is suitable for reference material or just reading material because of the completeness of the discussion. The explanation uses quite simple words with tables of explanations, parables, and illustrations that make it easier for the reader to understand its contents. The book's price is relatively cheap, and the size of the book is not too big and thick. The author uses a trusted reference source.

Behind the advantages, there are also drawbacks namely, the content of books that use scientific words that are not accompanied by their meaning. It uses a language style that is difficult to understand, so it is not enough one-time reading to understand it. Many repetitions of words make the reader a little confused - unrighteousness in composing subtitles and sentences that are not coherent. And the included image is only black and white so it looks monotonous and boring.

The suggestion for the author is to improve what has been mentioned in the lack of books, such as including the meaning of the scientific word used to facilitate the reader in understanding it without having to seek knowledge outside of this book, more attention to use words so as not to occur repetition of words that are ineffective and efficient, more attention to compose subtitles in the book so as not to confuse the reader, and more courageous to play colors on the illustration of the picture presented to attract the interest of the reader.

Teralita Fadilah Nur Pramuji \& Moses Glorino Rumambo Pandin Airlangga University

\section{REFERENCE}

1. Hidayat A. Filsafat Ilmu: Sejarah, Konsep, dan Strategi Pengembangan IPTKES. I. Bandung: ALFABETA,cv; 2020. 288 p.

\section{AUTHOR BIOGRAPHY}

Dr. Ade Hidayat, M.Pd. who is a lecturer in the foundation of education science (philosophy of educational sciences) at the University of Mathla'ul Anwar Banten. He is an alumnus of the Bachelor of Philosophy program at Gadjah Mada University (UGM). In 2012 completed the study of Master of Education Guidance and Counseling at the University of Education Indonesia. Then in 2019 earned a doctorate in the study program Guidance and Counseling Postgraduate UPI, Bandung. He has had many works such as articles in scientific journals, mass media, become editors and contributors to books, and is active as an editor and reviewer (bestari partner) of national and international journals. The work created contains interests in philosophy, guidance and counseling, psychology, and pedagogy. 